Research in Drama Education: The Journal of Applied Theatre and Performance

\title{
The impact of theatrical experiences on young adults in Spain
}

\section{Tomás Motos Teruel, Vicente Alfonso-Benlliure \& Donna Lee Fields}

To cite this article: Tomás Motos Teruel, Vicente Alfonso-Benlliure \& Donna Lee Fields (2018): The impact of theatrical experiences on young adults in Spain, Research in Drama Education: The Journal of Applied Theatre and Performance, DOI: 10.1080/13569783.2018.1494562

To link to this article: https://doi.org/10.1080/13569783.2018.1494562

曲 Published online: 25 Jul 2018.

Submit your article to this journal $\pi$

Џ Article views: 2

View Crossmark data ¿ 


\title{
The impact of theatrical experiences on young adults in Spain
}

\author{
Tomás Motos Teruel ${ }^{\mathrm{a}}$, Vicente Alfonso-Benlliure ${ }^{\mathrm{b}}$ and Donna Lee Fields ${ }^{c}$ \\ ${ }^{a}$ Department of Didactics and School Organization, University of Valencia, Valencia, Spain; ${ }^{b}$ Department of \\ Developmental and Educational Psychology, University of Valencia, Valencia, Spain; ' International University \\ of Valencia, Valencia, Spain
}

\begin{abstract}
This study examines how young adults experience theatre and how this activity impacts their personal development. A total of 305 subjects, between 14 and 29 years old, completed the 'Theatre

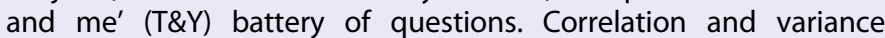
analysis were conducted considering age and gender. Older subjects reported that participating in drama activities has a greater impact on their lives, helps them to have a greater proclivity to take risks and to be more open-minded. With respect to gender, girls score higher than boys in 'Tolerance to RiskTaking and Commitment', 'Identity and Consciousness', Expression of Feeling' and 'Escape'.
\end{abstract}

\section{KEYWORDS}

Theatre; young adults; personal development; identity; creativity

This study is part of a research project that investigates implicit beliefs about and perceived impact of theatrical experience on adolescents and young adults in Spain. Over the long-term, the aim of the research project is to identify beliefs and, following this, contrast those beliefs with evidence relating to the actual development of young people taking part in theatre. A final stage of the research will compare the actual development of adolescents who practice theatre with those who have not accessed theatrical experience. The information contained in this article represents the first phase of the research: the exploration of implicit beliefs about and perceived impact of theatrical experience. The present work was carried out by a research group of the University of Valencia, all of whom have been involved for some years in the promotion of theatre as an educational resource. The aforementioned group is responsible for the organisation of the first university Master's degree in Applied Theatre in Spain. We have extensive experience in the theatrical training of young people and we seek to objectively investigate our subjective impressions that this training has positive effects on the integral development of young people.

From an educational perspective, theatre needs to be considered with both an artistic and pedagogical lens. This division (between art and pedagogy) is present in the AngloSaxon curriculum in both primary and secondary education. Nevertheless, in Spain, the opportunity to engage in theatre studies is found almost exclusively as extracurricular activities and formalised study has only minimal presence in any formal curriculum. Drama in primary school is seen solely as a strategy to teach literature and languages 
and in obligatory secondary studies (12-16 years old), theatre is included in only literature, language and physical education classes. Specific theatre studies can be found exclusively as an elective and only in the last year of this obligatory educational period (Performance Art and Dance).

More specifically, training in theatre given to students who take a curricular subject in Secondary Education or Baccalaureate in Spain focuses on three axes:

(a) Appreciation: implies the development of sensoperception. It includes 'warming up' activities, concentration and dramatisation.

(b) Expressivity: requires the students to use their knowledge, skills and techniques in the performing arts. Such as oral expression (expressive reading, diction and dynamisation of non-theatrical texts); writing of dramatic texts; body language and dramatisation and assembly of theatrical performances.

(c) Contextualisation: implies knowledge and understanding of artistic expressions in different historical moments and cultures. It focuses on knowledge of theatrical language; evaluating performances and understanding the basics of the history of the theatrical show.

On the other hand, theatre as an extracurricular activity focuses from two perspectives:

(a) Use of the drama process to create a theatrical event.

(b) Participation in the assembly and interpretation of an existing theatrical text.

Research in drama and theatre education suggests that theatre experiences give participants the opportunity to open up and tap into their inner potential, integrating different modes of expression (physical, verbal, visual, musical) from an interdisciplinary point of view (Motos 2009). Authors such as O'Neil (2005), Wagner (2002), Baldwin, Fleming, and Neelands (2003), Laferrière and Motos (2003), among others, have provided evidence to show that drama is an effective tool to develop such competences as linguistic communication, culture and art, social interactions and citizenship, learning to learn, autonomy, and personal initiative. Theatre scholars have particularly highlighted the positive impact dramatic forms have on participants for developmental factors such as overcoming shyness, developing self-knowledge and initiative, strengthening self-esteem, fostering creativity, and increasing verbal expression and communication. There are many studies that show that there is a close relationship between youth development and extracurricular activities (Tonkin et al. 2005) and theatrical studies (Belliveau 2005; Lazarus 2012; Navarro 2013).

But what do these young drama students truly perceive, believe and feel to be the benefits of theatrical studies? This is difficult to answer as there is a dearth of analytic studies on the impact that drama studies have on the personal and social development of this age group, scarcely any that focus on the beliefs these young people have about their involvement in the theatre, and none, to date, carried out in Spain. While in general youths in Spain are no different than the rest of those in the Western world with regard to their hobbies and leisure activities, interpersonal relationships, etc., there are some idiosyncrasies. For example, the relatively advanced age of the youth in leaving home, the stereotypical gender beliefs, and irregular job stability 
(Román 2015). These peculiarities may affect their implicit beliefs about the theatrical experience.

Implicit beliefs are fundamentally not conscious, and are tied to emotions, necessities and desires and, irrespective of the soundness of their rational basis, highly resistant to change (Sola-Fernández 2000). Given the intensity and frequency of change in the life of an adolescent, it is logical that their perceptions and beliefs make radical shifts from the time of their entry into this age range until they graduate to adulthood. Most likely, many make realistic evaluations of their theatrical experiences throughout this period, and some may also be more positive and intentional in their beliefs about the impact of participation. Nevertheless, there are no previous studies that can affirm these propositions.

In the same regard, little research is available that addresses the different experiences according to gender, though there is most decidedly evidence that this is a factor. From a study of adolescents and young adults through eight different sessions, Rodríguez and Araya (2009) found that boys were more likely than girls to report on having positive attitudes towards theatrical activities and physical expression. This partiality might be due to the fact that, given gendered expectations about behaviour, girls may have more experience in expressing themselves emotionally in other settings, while theatre may present a more rare opportunity for boys to express their feelings. Hughes and Wilson (2004) state that it is necessary to collect and analyse more data on the impact that theatre has on a personal development, in order to have a solid theoretical base that would explain the 'how' and 'why' of these effects on young people. According to these authors, one of the paths that must be explored is one which examines how the youths see their own evolution during their drama studies.

Most existing studies use an exclusively qualitative methodology. However, the present study combines qualitative and quantitative methodologies. It attempts to check if Spanish youths have similar self-perceptions and implicit beliefs about theatrical practice to those identified in other countries. The study also takes into account the differences in age and gender. From this, the following hypothesis can be presented:

1. Spanish youths place value on the positive influence of the theatrical experience on their personal development.

2. Implicit beliefs fostered by Spanish youths regarding the experience and impact drama studies have on their personal environment revolve around: self-knowledge, emotional expression, open-mindedness, problem solving and social skills.

3. There are significant differences between the younger and older participants with reference to how highly they value their involvement in theatrical studies and the impact they believe this has on their lives. Older participants place a higher and more positive value on these experiences.

4. There are significant differences between genders in how highly they value their theatrical experiences and the impact it has on their lives. Male students place more value in relation to their personal development. 


\section{Methodology and sample}

A total of 305 subjects participated in this study. All participants were involved with drama studies and acting: Either as a) students in the Valencia's High School of Dramatic Arts (ESAD); b) high school students specialising in artistic disciplines (Bachillerato Artístico); or c) students participating in theatre workshops for upper secondary education (ESO). The age range of the participants was between 14 and 29 with an average of 16.7 years. Thirty-four per cent of the participants were male and $66 \%$ were female. A qualitative study was carried out in parallel with the quantitative study. Part of the same sample (53 subjects; $28.3 \%$ males and $71.7 \%$ females) participated in six focus groups. This paper focuses only on the results of the quantitative study.

All participants completed the 'T\&Y, Theatre and me' Battery of questions (Motos and Alfonso-Benlliure 2017). T\&Y is made up of three scales: (1) 'Thoughts on Theatre' (PET), (2) 'Beliefs about the Theatrical Experience' (VET), and (3) 'Beliefs about the impact of the Theatrical Experience' (IET). The PET is a semantic differential test in which the subjects are asked to respond to a list of 16 adjectives presented in opposing sets (i.e. agree/disagree). The PET scale has three factors: (1) 'Affective Evaluation' (AE) that consists of an even number of adjectives, such as 'satisfactory/frustrating'. These are all evaluated in terms of the usefulness of theatre experiences. (2) 'Activity' (Ac) which includes adjectives related to the value of the active, creative and promising experience of participating in theatre (i.e. creative/not creative, varied/monotonous, etc.); and 3) 'Environment' (En) which includes adjectives such as 'easy/difficult' and 'secure/insecure', regarding the environment of the theatre activities.

The VET scale evaluates the implicit beliefs that students have with respect to participation in class, in theatre workshops, in skits, and acting in plays. It includes 29 items in the Likert scale (1-4), which range from strongly disagree to strongly agree. It has six factors:

Factor 1: 'Tolerance to Risk-Taking and Commitment' (RTC), which evaluated the implicit beliefs of the students with regards to taking risks and facing challenges (i.e. 'Acting implies taking risks and responding to challenges'.

Factor 2: 'Identity and Consciousness' (IC) evaluates beliefs relating to the effects drama studies have on positive identity and being conscious of exterior and interior realities (i.e. 'Theatre is a means and an opportunity to learn more about oneself and helps to establish one's own identity').

Factor 3: 'Expression of Feeling' (EF) explores beliefs about emotional expression (i.e. 'Theatre helps me lose my fear of exposing my feelings to others').

Factor 4: 'Open-mindedness' (OM) evaluates the effects acting in theatre has on attitudes towards self-exploration and learning (i.e. 'I have more freedom to be myself and I feel more comfortable in general').

Factor 5: 'Initiative' (In), explores personal beliefs surrounding the opportunities that theatre offers in putting one's own ideas into practice (i.e. 'I see my own ideas being represented in plays').

Factor 6: 'Escape' (Es) addresses the vision of the theatrical experience as an opportunity to forget and escape from one's problems (i.e. 'It is a space and an opportunity to escape from toxic environments at home and at school'). 
Finally, the 'Beliefs about the Impact of the Theatrical Experience' (IET) scale consists of 10 items relating to the implicit beliefs students have regarding the impact that theatre has on them. It was analysed through a Likert scale in which the subjects respond according to their level of comfort ( 1 - 'not at all', to 4 - 'a lot').

The three scales show an adequate level of reliability in terms of their Cronbach's alpha coefficient. This coefficient is a weighted average of the correlations between the items that are part of the scale. Specifically, these indices were .75 (PET), .82 (VET) and .94 (IET). The process of the design, construction and validation of the battery of questions of T\&Y can be consulted in Motos and Alfonso-Benlliure (2017).

The analyses were carried out using the SPSS 24 statistical package.

\section{Results}

In order to explore the relationship between the assessment that young people make about the theatrical experience (PET scale) and their implicit theories about that experience (VET scale), Pearson's correlation coefficient was calculated (see Table 1).

With respect to the PET's total score, there is a strong relation with all the VET's factors, above all 'Expression of Feelings' $(r=.41, p<.01)$, 'Escape' $(r=.38, p<.01)$ and 'Identity and Consciousness' $(r=.38, p<.01)$. This suggests that young people who value the theatrical experience in a more positive way, consider that it facilitates the emotional expressiveness, the feeling of escape and helps them to explore their identities. Of course, it can also be said that subjects who understand theatrical activities this way value the experience more positively. With respect to the VET's total score, there is a significant relationship with all the PET's factors, especially 'Affective Evaluation' $(r=.62, p<.01)$. This implies that young people with consolidated beliefs have a tendency to make more affective evaluations (satisfactory, pleasant). Criteria linked to the nature of the activity (creative, active) or the environment where it takes place (secure, easy-going) play a secondary role in their assessments. Finally, correlation analysis between PET and VET scales and the impact that young people perceive on their own personal development (IET scale) show that most of the correlations are significant. Affective Evaluation $(r=.32, p<.01)$, Identity and Consciousness $(r=.48, p<.01)$ and Open-Mindedness $(r=.43, p<.01)$ stand out above the others. Again, these suggest that when the theatrical experience is evaluated in affective terms, beliefs are more positive and perceived impact is higher than when a more intellectual or pragmatic evaluation is undertaken. And also, that young people consider that

Table 1. Pearson's correlations between the scales of the 'T\&Y Battery'.

\begin{tabular}{|c|c|c|c|c|c|c|c|c|c|c|c|}
\hline & \multicolumn{8}{|c|}{ VET } & \multicolumn{3}{|c|}{ PET } \\
\hline & RTC & IC & $\mathrm{EF}$ & $\mathrm{OM}$ & $\ln$ & Es & Total & $\mathrm{AE}$ & $A c$ & En & Total \\
\hline \multicolumn{12}{|l|}{ PET } \\
\hline Affective Ev. (AE) & $.39^{* *}$ & $.44^{* *}$ & $.42^{* *}$ & $.41^{* *}$ & $.24^{* *}$ & $.38^{* *}$ & $.62^{* *}$ & & & & \\
\hline Activity (Ac) & $.33^{* *}$ & $.33^{* *}$ & $.35^{* *}$ & $.31^{* *}$ & $.12^{*}$ & $.31^{* *}$ & $.52^{* *}$ & & & & \\
\hline Environment (En) & $.14^{* *}$ & $.19^{* *}$ & $.28^{* *}$ & $.20^{* *}$ & & $.27^{* *}$ & $.39^{* *}$ & & & & \\
\hline TOTAL PET & $.34^{* *}$ & $.38^{* *}$ & $.41^{* *}$ & $.37^{* *}$ & $.17^{* *}$ & $.38^{* *}$ & $.61^{* *}$ & & & & \\
\hline \multicolumn{12}{|l|}{ IET } \\
\hline TOTAL IET & $.38^{* *}$ & $.48^{* *}$ & $.40^{* *}$ & $.43^{* *}$ & $.30^{* *}$ & $.41^{* *}$ & $.63^{* *}$ & $.32^{* *}$ & $.23^{* *}$ & $.15^{* *}$ & $.28^{* *}$ \\
\hline
\end{tabular}


taking part in theatrical activities has a very strong impact on how they see themselves, and the open-mindedness and flexibility with which they relate to others.

The results of the correlations between the scores regarding scales and the age variable are shown in Table 2. Older students score higher in 'Affective Evaluation' and lower in 'Environment' at PET scale. With respect to VET scale, older subjects feel that their participation in the theatre helps them to cope with risk (RTC), to define their own identity (IC), to be more open-minded (OM), and to take more personal initiatives (In). Finally, older subjects also indicate higher values with regard to the impact of theatre on their lives (IET).

Table 3 shows means and standard deviations according to gender and age. A Variance Analysis (ANOVA) was conducted by separating participants in two groups: aged 18 and above, and up to 18 years old. While there were no significant differences between the two groups in the PET (Though about Theatre) total scores $\left(F_{(1,304)}=9,353, p>.05\right.$ ), there was a significant difference in 'Affective Evaluation' $\left(F_{(1,304)}=7,483, p>.01\right)$ and 'Environment' $\left(F_{(1,304)}=15,333, p>.01\right)$. Older participants considered the theatrical experience more useful; however, the younger subjects found them to be more comfortable and agreeable.

With respect to the VET scale (Beliefs about Participating in Theatre Experiences), we found significant differences in total scores $\left(F_{(1,304)}=4,077, p>.05\right)$, and in the 'Tolerance to Risk and Compromise' $\left(F_{(1,304)}=11,489, p>.01\right)$, 'Identity and Self-knowledge' $\left(F_{(1,304)}=\right.$ $5,784, p>.05)$, 'Open-mindedness' $\left(F_{(1,304)}=12,337, p>.01\right)$, and 'Initiative' $\left(F_{(1,304)}=\right.$ $11,570, p>.01)$ factors. All these differences were weighted higher in the group of older participants, which means that older participants agreed more frequently with these beliefs. With respect to Beliefs about the impact of the Theatrical Experience (IET), no significant differences were found between the two groups $\left(F_{(1,304)}=0.172, p>.05\right)$.

In order to analyse the differences between male and female participants in their responses to T\&Y scales, Analysis of Variance (ANOVA) was performed. The results show that, with respect to the PET scale, there are no significant differences between genders $\left(F_{(1,380)}=1,737, p>.05\right)$; however, there were differences in relation to the 'Environment' factor $\left(F_{(1,380)}=4,962, p<.05\right)$. Males value the environment created in theatrical studies as comfortable and safe. With respect to VET scale, there are significant differences between genders in the total scores $\left(F_{(1,380)}=11,286, p<.01\right)$, and the factors of 'Tolerance to Risk-Taking and Commitment' $\left(F_{(1,380)}=8,959, p<.01\right)$, 'Identity and Consciousness' $\left(F_{(1,380)}=21,870, p<.01\right)$, Expression of Feeling' $\left(F_{(1,380)}=4,326, p<.01\right)$ and 'Escape' $\left(F_{(1,380)}=6,439, p<.01\right)$. In all these factors girls score significantly higher than boys.

Table 2. Pearson correlations between 'T\&Y scales' and age.

\begin{tabular}{|c|c|c|c|}
\hline & Age & & Age \\
\hline VET & & PET & \\
\hline Total & $.12^{*}$ & $\overline{\text { Total }}$ & \\
\hline RTC & $.21^{* * *}$ & $\mathrm{AE}$ & $.15^{* *}$ \\
\hline IC & $.12^{* *}$ & $A C$ & \\
\hline $\mathrm{EF}$ & & En & $-.16^{* *}$ \\
\hline $\mathrm{OM}$ & $.18^{* *}$ & & \\
\hline In & $.13^{*}$ & IET & \\
\hline Es & & $\overline{\text { Total }}$ & $.11^{*}$ \\
\hline
\end{tabular}

Note: RTC: Risk-Taking and Commitment; IC: Identity Consciousness; EF: Expression of Feeling; OM: Open-Mindedness; In: Initiative; Es: Escape; AE: Affective Evaluation; Ac: Activity; En: Environment. 
Table 3. Means and standard deviations by age and gender.

\begin{tabular}{|c|c|c|c|c|c|c|}
\hline Scale & Factor & & $\leq 18$ years old & $>18$ years old & Female & Male \\
\hline \multirow[t]{8}{*}{ PET } & $\mathrm{AE}$ & $M$ & 25.12 & 27.88 & 25.69 & 26.04 \\
\hline & & S.D & 5.12 & 1.92 & 5.29 & 3.09 \\
\hline & Ac & $M$ & 25.72 & 27.20 & 25.99 & 26.28 \\
\hline & & S.D & 5.13 & 2.34 & 4.96 & 3.90 \\
\hline & En & $M$ & 11.84 & 10.83 & 11.28 & 12.23 \\
\hline & & S.D & 2.99 & 2.65 & 3.20 & 2.17 \\
\hline & TOTAL & M & 62.68 & 65.90 & 62.96 & 64.56 \\
\hline & & S.D & 11.97 & 5.49 & 12.15 & 7.23 \\
\hline \multirow[t]{14}{*}{ VET } & RTC & $M$ & 26.06 & 28.63 & 27.07 & 25.92 \\
\hline & & S.D & 5.70 & 2.64 & 4.83 & 5.93 \\
\hline & IC & $M$ & 20.31 & 21.00 & 20.90 & 19.62 \\
\hline & & S.D & 4.07 & 2.41 & 3.81 & 3.41 \\
\hline & EF & $\mathrm{M}$ & 19.45 & 20.35 & 19.83 & 17.34 \\
\hline & & S.D & 4.85 & 3.16 & 4.37 & 4.77 \\
\hline & $\mathrm{OM}$ & $M$ & 12.08 & 13.42 & 12.49 & 12.25 \\
\hline & & S.D & 3.04 & 2.35 & 3.10 & 2.60 \\
\hline & In & $\mathrm{M}$ & 9.17 & 9.83 & 9.40 & 9.19 \\
\hline & & S.D & 2.43 & 1.08 & 2.08 & 2.43 \\
\hline & Es & $M$ & 12.45 & 12.80 & 12.63 & 10.35 \\
\hline & & S.D & 3.39 & 3.03 & 3.45 & 2.98 \\
\hline & TOTAL & $M$ & 102.89 & 109.53 & 105.81 & 101.94 \\
\hline & & S.D & 19.44 & 10.86 & 19.06 & 14.99 \\
\hline \multirow[t]{2}{*}{ IET } & TOTAL & $M$ & 30.49 & 31.15 & 31.02 & 29.90 \\
\hline & & S.D & 7.85 & 8.78 & 8.19 & 7.84 \\
\hline
\end{tabular}

Finally, with respect to IET scale, responses from girls show significantly higher global scores than boys $\left(F_{(1,380)}=4,161, p<.05\right)$.

\section{Discussion and conclusions}

This study focused on ascertaining the beliefs, opinions and values manifested by adolescents and young adults with respect to the connection the theatre has on their personal life. Our discussion here focuses on the results of a quantitative study but it is important to note that our a parallel qualitative study, using focus groups, confirms existing research and the findings of the quantitative study (see Motos \& Alfonso-Benlliure, forthcoming). The two methodological approaches offered a complementary but also congruent vision. In both cases, the first hypothesis - that drama activities have positive effects on their lives in the short- and long-term - was confirmed by the participants.

The second hypothesis - regarding the implicit beliefs the participants showed while actively participating - also confirmed that the Spanish youth share a similar view regarding theatre and personal development and how this is affected by drama activities. The most notable factors that surfaced repeatedly were those having to do with self-knowledge and personal identity, emotional expression and open-mindedness. The young 'actors' stated that their drama studies helped them significantly with regard to developing their internal and external identities and abilities (loss of the sense of shame while acting, speaking or doing any other type of activity in front of others; becoming more open and uninhibited).

The quantitative analysis allowed us to study these perceived effects depending on age and gender. Results confirm the third hypothesis: older adolescents value theatrical 
experiences in a more positive way than younger ones. They consider it more useful, see more advantages for themselves and recognise that it helps them to develop even more than younger students. The older students value their experiences in the theatre more positively and see that it helps them to learn to deal with challenges, to make commitments, to see themselves in a more complex way, to be more conscious of what is around them and to be able to make decisions. They also think that these effects will endure over the long term.

With respect to the differences in gender, results confirmed expected differences, though with some nuances. The female participants have more positive experiences than males and they perceive that the impact of drama activities transfers to other parts of their lives. Female participants mostly value the help their experiences in the theatre have given them in tolerating new and unknown situations, in exploring their own identities, getting to know and express their emotions, and in escaping daily life. Male participants feel more strongly than females about the safety and comfort they feel the theatre affords them. Rodriguez and Araya (2009) have also found an increase in male subjects in optimism related to theatre and physical experience after their acting classes.

In general, these results confirm and compliment the research carried out by Hughes and Wilson (2004) on the impact theatre has on the personal and social development of young adults. Our next step will be to contrast these young people's perceptions with objective assessments of their learning and development in terms of self-esteem, identity, risk tolerance, etc. Nevertheless, this study has limitations. For example, all participants were engaged in theatre activities. What would have happened to our results if we had incorporated young people with no theatrical experience or students who tried theatre but did not persist with it?

Nonetheless, our research affirms that the resources, experiences and opportunities that drama activities offer help young people to reach vital benchmarks in their lives. Although there is still much to investigate, it seems that theatre, despite being an ephemeral art form, always leaves its mark.

\section{Disclosure statement}

No potential conflict of interest was reported by the authors.

\section{Notes on contributors}

Tomás Motos Teruel Pedagogue and psychologist specialised in creativity, theatre and corporal expression, who has been a tenured professor in the University of Valencia of Didactics and School Organization. He holds a PhD in Philosophy and Educational Sciences. He is the co-director of the Master degree in Applied Theatre at the University of Valencia.

Vicente Alfonso-Benlliure PhD in psychology. Research focuses on the evaluation and stimulation of creativity from childhood to advanced adulthood. He is the author of the Children's Creativity Test (TCl) for elementary school children. Teacher of the Master of Special Education (Intervention with gifted children). Co-director of the Master's degree in Applied Theater (UV).

Donna Lee Fields Associated Professor at the International University of Valencia. Visiting Professor at the University of Valencia. 


\section{References}

Baldwin, P., K. Fleming, and J. Neelands. 2003. Teaching Literacy Through Drama: Creative Approaches. London: Routledge Falmer.

Belliveau, G. 2005. "An Arts-Based Approach to Teach Social Justice: Drama as a way to Address Bullying in Schools." International Journal of Arts Education 3: 136-165.

Hughes, J., and K. Wilson. 2004. "Playing a Part: The Impact of Youth Theatre on Young People's Personal and Social Development." Research in Drama Education: The Journal of Applied Theatre and Performance 9 (1): 57-72.

Laferrière, G., and T. Motos. 2003. Palabras para la acción. Ciudad Real: Ñaque.

Lazarus, J. 2012. Sings of Change: New Directions in Theatre Education. Chicago, IL: Intellect.

Motos, T. 2009. "El teatro en la Educación Secundaria. Fundamentos y retos." Creatividad y Sociedad 14. http://www.creatividadysociedad.com/articulos/14/3-el_teatro_en_la_educ\%20secundaria_ tomas_motos.pdf (date of search, December, 2016).

Motos, T., and V. Alfonso-Benlliure. 2017. "'El teatro y yo': evaluación del impacto del teatro en los jóvenes"." Crearmundos 15: 346-352.

Motos, T., and V. Alfonso-Benlliure. Forthcoming. El teatro como recurso para afrontar los retos de la adolescencia. Didacticae.

Navarro, A. 2013. Teatro para el cambio. Nuevos enfoques del Teatro en la Educación. Ñaque. Online book http://www.naque.es/virtuemart/179/16/ebook/manuales/teatro-para-el-cambio-en-laeducacion-nuevos-enfoques-detail (date of search: December, 2016).

O'Neil, C. 2005. Drama Worlds. A Framework for Process Drama. Toronto: Pearson Education Canada.

Rodríguez, V., and G. A. Araya. 2009. "Efecto de ocho clases de expresión corporal en el estado de ánimo y autoconcepto general de jóvenes universitarios." Revista de Educación 33 (2): 139-152.

Román, H. 2015. La identidad social de los adolescentes españoles de principios del siglo XXI: Un estudio de las respuestas a la pregunta «quién soy yo». Doctoral Thesis. University of Salamanca.

Sola-Fernández, M. 2000. "La formación de creencias ideológicas y su influencia en el pensamiento profesional." In Profesorado y Reforma: iun cambio en las prácticas de los docentes?, edited by I. Rivas Flores, 73-80. Málaga: Aljibe.

Tonkin, R.S., A. Murphy, Z. Lee, E. Saewyc, and The McCreary Centre Society. 2005. British Columbia Youth Health Trends: A Retrospective, 1992-2003. Vancouver, BC: The McCreary Centre Society.

Wagner, B. J. 2002. "Understanding Drama-Based Education." In Body and Language: Intercultural Learning Through Drama, edited by G. Brauer, 3-18. Westport, CT: Ablex Publishing. 